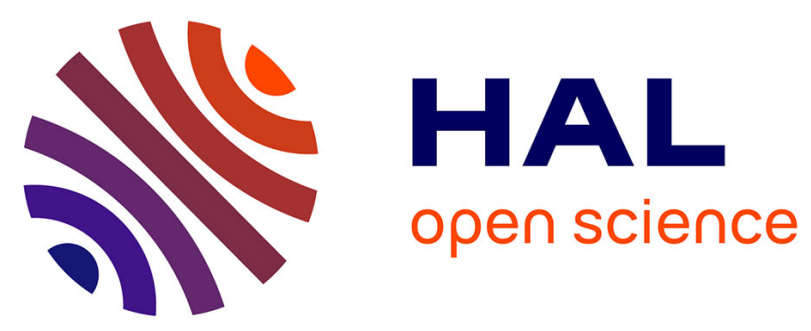

\title{
Parameters affecting thermal risk through a kinetic model under adiabatic condition: Application to liquid-liquid reaction system
}

Sébastien Leveneur, M. Pinchard, A. Rimbault, Mostafa Safdari Shadloo, T. Meyer

\section{To cite this version:}

Sébastien Leveneur, M. Pinchard, A. Rimbault, Mostafa Safdari Shadloo, T. Meyer. Parameters affecting thermal risk through a kinetic model under adiabatic condition: Application to liquid-liquid reaction system. Thermochimica Acta, 2018, 666, pp.10-17. 10.1016/j.tca.2018.05.024 . hal-02127857

\section{HAL Id: hal-02127857 \\ https://hal.science/hal-02127857}

Submitted on 13 Jan 2022

HAL is a multi-disciplinary open access archive for the deposit and dissemination of scientific research documents, whether they are published or not. The documents may come from teaching and research institutions in France or abroad, or from public or private research centers.
L'archive ouverte pluridisciplinaire HAL, est destinée au dépôt et à la diffusion de documents scientifiques de niveau recherche, publiés ou non, émanant des établissements d'enseignement et de recherche français ou étrangers, des laboratoires publics ou privés. 


\section{Parameters affecting thermal risk through a kinetic model under adiabatic condition}

\section{: Application to liquid-liquid reaction system}

Sébastien Leveneur ${ }^{* 1,2}$, Maxime Pinchard ${ }^{1}$, Antoinette Rimbault ${ }^{1}$, Mostafa Safdari Shadloo ${ }^{4}$, Thierry Meyer ${ }^{3}$

${ }^{1}$ Normandie Univ, INSA Rouen, UNIROUEN, LSPC, EA4704, 76000 Rouen, France, E-mail : sebastien.leveneur@insa-rouen.fr

${ }^{2}$ Laboratory of Industrial Chemistry and Reaction Engineering, Johan Gadolin Process Chemistry Centre, Åbo Akademi University, Biskopsgatan 8, FI-20500 Åbo/Turku, Finland.

${ }^{3}$ EPFL, Ecole Polytechnique Fédérale de Lausanne, Institute of Chemical Sciences and Engineering, Group of Physical and Chemical Safety, ISIC-GSCP, Station 6, 1015 Lausanne, Switzerland.

${ }^{4}$ CORIA Lab. / CNRS, University and INSA of Rouen, 76000 Rouen, France 


\section{ABSTRACT}

Risk of thermal runaway for epoxidation is not negligible and should be analyzed and assessed. In industry, epoxidation of vegetable oils is carried out by the oxidation of Prileschajew, involving the in situ production of percarboxylic acid from hydrogen peroxide and the corresponding carboxylic acid. Different research groups have developed kinetic models under isothermal or isoperibolic mode for this liquid-liquid reaction system. Nevertheless, none of them have built a kinetic model under adiabatic mode. Such kinetic model under adiabatic condition is important to evaluate the thermal risk of a process.

During this study, a kinetic model was built for the epoxidation of cottonseed oil by peracetic acid by using ARSST system, which works under near-adiabatic condition. This kinetic model can fit the experimental reaction temperature. Then, based on this model, the influence of different inlet parameters (i.e. initial temperature and concentrations) on safety parameters, i.e., Time-to-Maximum rate under adiabatic conditions and adiabatic temperature rise was investigated.

KEYWORDS: kinetic modeling, liquid-liquid reactions, adiabatic calorimeter, thermal risk assessment, epoxidation. 


\section{HIGHLIGHTS}

A kinetic model for complex chemical system under adiabatic condition was developed

$\Delta \mathrm{T}_{\mathrm{ad}}$ and $\mathrm{TMR}_{\mathrm{ad}}$ in presence of several exothermic reactions were determined

Thermal risk assessment for the epoxidation of vegetable oil were performed 


\section{INTRODUCTION}

Energy sector and chemical industry still depend on the use of fossil raw materials. As example, Speight (2016) [1] reported that $90 \%$ of organic chemicals are produced from natural gas or petroleum. Recently, academies, industries and public authorities have put a great effort to develop new processes and new chemicals using renewable feedstock.

The use of vegetable oils, as a renewable feedstock, for the production of chemicals or biofuels is a good illustration of this effort. The worldwide production of vegetable oil is increasing since 1975 [2]. The part of production for industrial uses also increases and not only for biodiesels [3]. Vegetable oils can be considered as platform molecules [4-6].

Among the different functionalization of vegetable oils, there is the epoxidation of vegetable oils. Epoxidized vegetable oils are important chemicals for the production of non-isocyanate polyurethanes [7-13], biolubricants [14-18], plasticizers [19-20] or stabilizers for polymers. Several routes for the production of epoxidized vegetable oils exist. One of the more eco-friendly methods is the use of oxygen or hydrogen peroxide [21], however, the research on catalyst is still ongoing [2228]. The use of enzymes is an alternative that is being more and more applied [29-36].

For these reasons, at the industrial scale, the Prileschajew oxidation is the most used process [37-41]. Prileschajew oxidation is a liquid-liquid process where a percarboxylic acid is produced in situ in the aqueous phase from the perhydrolysis reaction, and diffused into the organic phase to epoxide the unsaturated groups of the vegetable oils. Solubility in the organic phase and reactivity of percarboxylic acid are higher compared to hydrogen peroxide. However, one of the main drawbacks of this reaction system is the risk of thermal runaway induced by several consecutive exothermic reactions [42-48]. 
The aforementioned articles have studied thermal risks and/or thermal instabilities of this chemical system. Nevertheless, none of them has built a kinetic model under adiabatic conditions, including secondary reactions as the decomposition of peroxide species. This work proposes to fill this gap by building a kinetic model for the epoxidation of cottonseed oil by peracetic acid produced in situ. The benefit of such model compared to the zero-order approach [49] is that one can estimate the safety parameters at different initial operating conditions.

Based on this model, safety parameters such as the time to maximum rate under adiabatic conditions, $\mathrm{TMR}_{\mathrm{ad}}$, and the adiabatic temperature rise, $\Delta \mathrm{T}_{\mathrm{ad}}$, are estimated. These safety parameters are necessary to make a thermal risk assessment because while the latter represents the severity of a thermal risk, the former signifies its probability. The influence of reactant, catalyst concentrations and the initial temperature on these safety parameters are studied in the current work. 


\section{EXPERIMENTAL SECTION}

\subsection{Chemicals}

To perform the experiments in the Advanced Reactive System Screening Tool (ARSST) system, the following chemicals were used: distilled water, hydrogen peroxide (33 wt \%, VWR International), acetic acid (>99\%, Alfa Aesar GmbH \& Co.) and cottonseed oil (ThermoFisher Scientific GmbH).

\subsection{Experiments performed in ARSST}

ARSST system is a calorimeter which can work under near-adiabatic conditions by using the principle of heat loss compensation [7-10, 17, 42,49]. It yields critical experimental knowledge of the rates of temperature and pressure rise during a runaway reaction. The detailed description of the ARSST equipment can be found in our previous articles [42, 49].

The system consists of an open glass cell reactor surrounded by a heater belt. This glass cell reactor is put in an insulation sheath, which is put in a pressurized vessel. The vessel is pressurized under 35 bar of nitrogen to limit the evaporation of the liquid phase. Through the heater belt, a background heating rate $\beta$ is applied to the reaction mixture.

In order to build a kinetic model, taking into account different inlet parameters such as reactant and catalyst concentrations or background heating rate, Table 1 shows the experimental matrix. 
Table 1: Experimental matrix

\begin{tabular}{|c|c|c|c|c|c|c|c|c|c|}
\hline \multirow[b]{2}{*}{ RUN } & \multicolumn{5}{|c|}{ Initial concentration $\left(\mathrm{mol}^{\left.-\mathrm{L}^{-1}\right)}\right.$} & \multirow[b]{2}{*}{$\mathbf{V}_{\text {org }}(\mathbf{L})$} & \multirow[b]{2}{*}{$\mathbf{V}_{\text {aq }}(\mathbf{L})$} & \multirow[b]{2}{*}{$\beta\left({ }^{\circ} \mathrm{C} \cdot \mathrm{min}^{-1}\right)$} & \multirow[b]{2}{*}{ Initial T1 $\left({ }^{\circ} \mathbf{C}\right)$} \\
\hline & {$[D B]_{\text {org }}$} & {$[\mathrm{HP}]_{\mathrm{aq}}$} & {$[\mathbf{A A A}]_{\mathrm{aq}}$} & {$[\mathrm{W}]_{\mathrm{aq}}$} & {$\left[\mathrm{H}_{2} \mathrm{SO}_{4}\right]_{\mathrm{aq}}$} & & & & \\
\hline 1 & 3.9 & 4.75 & 4.15 & 35.95 & 0 & 0.0036 & 0.0057 & 4.04 & 22.58 \\
\hline 2 & 3.9 & 5.12 & 4.47 & 34.11 & 0.11 & 0.0034 & 0.0053 & 0.89 & 22.58 \\
\hline 3 & 3.9 & 4.45 & 4.02 & 35.25 & 0.52 & 0.0035 & 0.0058 & 2.12 & 20.23 \\
\hline 4 & 3.9 & 4.7 & 3.51 & 36.41 & 0.56 & 0.0034 & 0.0057 & 0.9 & 27.37 \\
\hline 5 & 3.9 & 5.37 & 4.14 & 33.57 & 0.53 & 0.0034 & 0.0057 & 1.83 & 24.08 \\
\hline
\end{tabular}




\section{RESULTS AND DISCUSSION}

3.1 Kinetics, mass and energy balances

\subsubsection{Kinetics}

Epoxidation of vegetable oils by Prileschajew oxidation is a liquid-liquid reaction system, where peracetic acid (PAA) is produced in the aqueous phase from the perhydrolysis reaction. Then, PAA diffuses to the organic phase to epoxidize the unsaturated groups.

Different side reactions, such as decomposition of peroxide species (hydrogen peroxide and PAA) or ring-opening reactions by different nucleophiles, can occur. Fig. 1 shows the different reactions occurring in the aqueous phase. As shown in previous papers [42, 47], the decomposition of hydrogen peroxide during this process can be neglected.

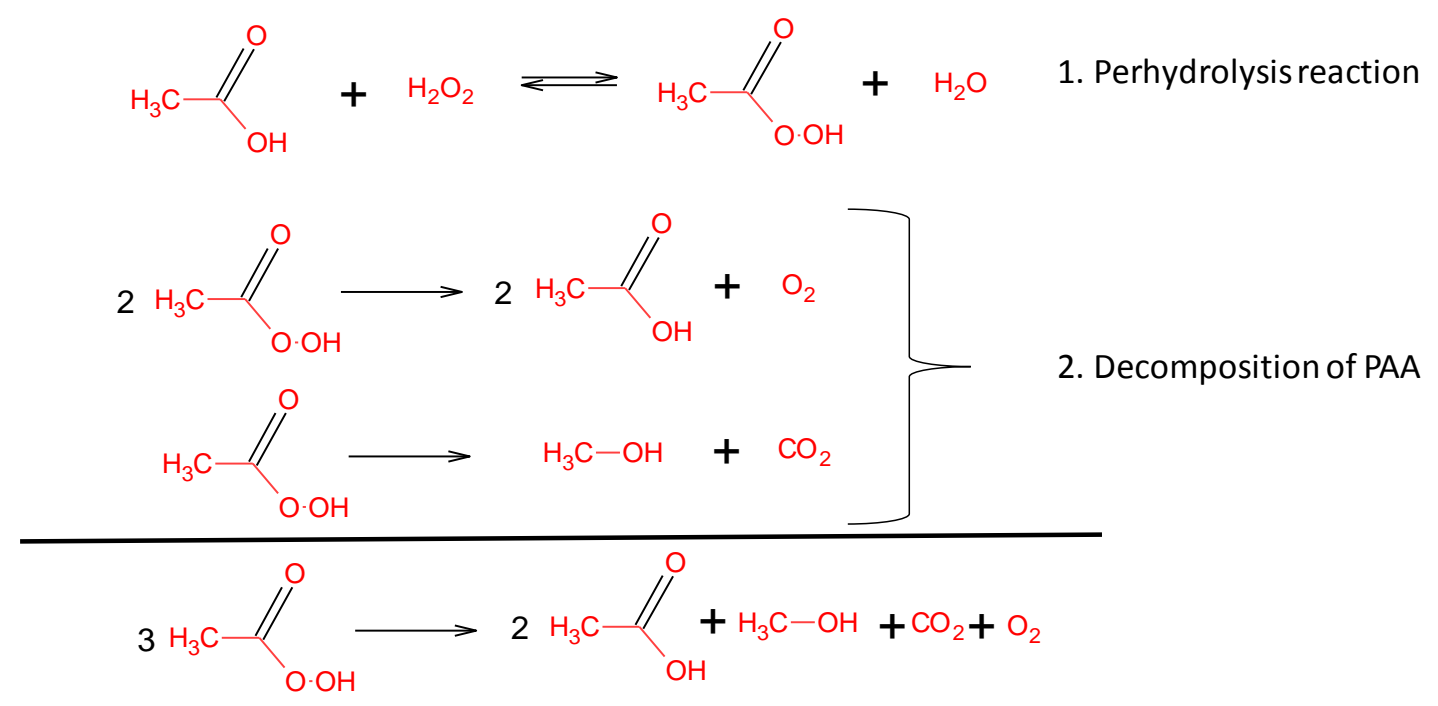

Figure 1: Reactions in the aqueous phase.

Perhydrolysis reaction rate can be expressed as [50]: 
$r_{\text {perh }}=k_{\text {perh }} \cdot \frac{\left[\mathrm{H}_{3} \mathrm{O}^{+}\right]_{a q}}{\left[\mathrm{H}_{2} \mathrm{O}\right]_{a q}}\left([\mathrm{AA}]_{a q} \cdot\left[\mathrm{H}_{2} \mathrm{O}_{2}\right]_{a q}-\frac{1}{K^{C}} \cdot[\mathrm{PAA}]_{a q} \cdot\left[\mathrm{H}_{2} \mathrm{O}\right]_{a q}\right)$

where, $K^{C}$ is the equilibrium constant based on the concentrations and can be expressed as:

$K^{C}=\delta \cdot\left[H_{2} S_{4}\right]_{a q}+K^{T}$

Here, the parameter $\delta$ takes into account the non-ideality of the reaction mixture, and $K^{T}$ is the true thermodynamic constants, which can be expressed by a law of van't Hoff. To determine the value of $K^{C}$ with temperature and sulfuric acid concentration, the parameters from the work of Leveneur et al. [50] were used.

The concentration of hydroxonium ions in the aqueous phase can be derived by taking into account the electroneutrality of the reaction mixture and the mass balance of sulfuric and acetic acids:

$\left[\mathrm{H}_{3} \mathrm{O}^{+}\right]_{a q}=\frac{1}{2}\left[\mathrm{H}_{2} \mathrm{SO}_{4}\right]_{a q}+\sqrt{\frac{\left[\mathrm{H}_{2} \mathrm{SO}_{4}\right]_{a q}{ }^{2}}{4}+2 \cdot K_{I I}^{C} \cdot\left[\mathrm{H}_{2} \mathrm{SO}_{4}\right]_{a q} \cdot\left[\mathrm{H}_{2} \mathrm{O}\right]_{a q}+K_{I I I}^{C} \cdot\left[\mathrm{H}_{2} \mathrm{O}\right]_{a q} \cdot[A A]_{a q}}(3)$

where, $K_{I I}^{C}$ and $K_{I I I}^{C}$ are the dissociations constants for the second dissociation of sulfuric acid and acetic acid, respectively [51-52].

As described by Musakka et al. [53] and Leveneur et al. [54], the decomposition of percarboxylic acid can follow two reaction pathways (also illustrated in Fig. 1). To minimize the number of parameters to estimate, these two decomposition reactions were represented in one reaction. The kinetic expression for the decomposition of PAA can be expressed as:

$r_{\text {decomp_PAA }}=k_{\text {decomp_ } P A A} \cdot[P A A]_{a q} \cdot\left[H_{3} O^{+}\right]_{a q}$ 


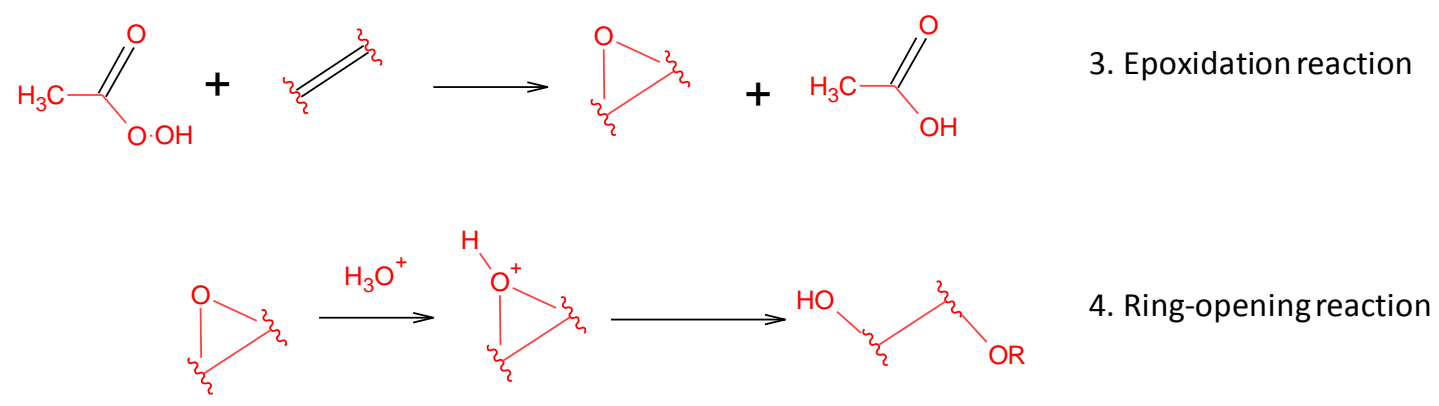

Figure 2: Reactions in aqueous phase.

Fig. 2 exhibits the reactions in the organic phase. In the organic phase, two main reactions occur, namely, epoxidation reaction and ring-opening reactions. For the ring-opening reaction, several nucleophile agents can open the oxirane ring: water, acetic and peracetic acid or hydrogen peroxide. In our earlier work [37], we have demonstrated that ring-opening by percarboxylic acid is the fastest one. For that reason, here, we have only considered the ring-opening by percarboxylic acid.

The kinetics of epoxidation and ring-opening by peracetic acid can be expressed to

$$
\begin{aligned}
& r_{\mathrm{Ep}}=k_{\mathrm{Ep}} \times[\mathrm{PAA}]_{\mathrm{aq}} \times[\mathrm{DB}]_{\mathrm{org}} \\
& r_{\mathrm{RO}}=k_{R O} \times[\mathrm{Ep}]_{\mathrm{org}} \times[\mathrm{PAA}]_{\mathrm{aq}} \times\left[\mathrm{H}_{3} \mathrm{O}^{+}\right]_{\mathrm{aq}}
\end{aligned}
$$




\subsubsection{Mass balance}

This section consists in describing the mass balance of the different compounds in aqueous and organic phases. By assuming that interfacial mass transfer is faster than chemical reaction [37-38, 44], mass balance in the organic and aqueous phases can be expressed as:

$\frac{d C_{i, o r g}}{d t}=(\propto . K i+1-\propto)^{-1} \cdot\left[\propto \sum v_{i j} \cdot r_{a q, j}+(1-\propto) \sum v_{i j} \cdot r_{o r g, j}\right]$

$\frac{d C_{i, a q}}{d t}=\left(\propto+\frac{1-\propto}{K i}\right)^{-1} \cdot\left[\propto \sum v_{i j} \cdot r_{a q, j}+(1-\propto) \sum v_{i j} \cdot r_{o r g, j}\right]$

where, $\propto^{-1}=\frac{V_{a q}}{V_{T}}$ and $\mathrm{K}_{i}=\left(\frac{C_{i, a q}}{C_{i, \text { org }}}\right)_{\text {equilibrium }}$.

Here, the solubilities of water and hydrogen peroxide in the organic phase were assumed to be negligible, i.e., $\mathrm{K}_{\mathrm{W}}, \mathrm{K}_{\mathrm{AA}}, \mathrm{K}_{\mathrm{PAA}}$ and $\mathrm{K}_{\mathrm{Hp}} \rightarrow \infty$. Additionally, the solubilities of vegetables and their derivatives in the aqueous phase were assumed to be negligible, i.e., $\mathrm{K}_{\mathrm{cotton}}, \mathrm{K}_{\mathrm{Ep}}, \mathrm{K}_{\mathrm{RO}} \rightarrow 0$ [38]. Thus, mass balance for each compound can be expressed as:

$$
\begin{aligned}
& \frac{d C_{A A, a q}}{d t}=\left(-r_{\text {perh }}+2 * r_{\text {decomp_PAA }}\right)+\frac{(1-\propto)}{\propto} * r_{E p} \\
& \frac{d C_{W, a q}}{d t}=r_{p e r h} \\
& \frac{d C_{H P, a q}}{d t}=-r_{p e r h} \\
& \frac{d C_{P A A, a q}}{d t}=\left(r_{p e r h}-3 * r_{d e c o m p} p_{P A A}\right)-\frac{(1-\propto)}{\propto} * r_{E p} \\
& \frac{d C_{D B, o r g}}{d t}=-r_{E p} \\
& \frac{d C_{E p, o r g}}{d t}=r_{E p}-r_{R O}
\end{aligned}
$$


$\frac{d C_{R O}}{d t}=r_{R O}$

\subsubsection{Heat balance}

Heat balance in the liquid phase can be expressed as [42, 49, 55]:

$\varphi \cdot m_{R} \cdot \hat{C}_{P_{R}} \cdot \frac{d T_{R}}{d t}=q_{r x}+q_{\text {elec }}$

where, $\varphi$ is the thermal inertia factor, and is expressed as $\varphi=\frac{m_{R} \cdot \hat{C}_{P_{R}}+m_{\text {ins }} \cdot C_{P_{\text {ins }}}}{m_{R} \cdot \hat{C}_{P_{R}}}$. The term qelec. is the electrical power provided to the reaction mixture through the heater belt. By dividing this term by $\varphi . m_{R} . \hat{C}_{P_{R}}$, one gets the electrical heating background $\beta$.

The heat-flow rate due to the chemical reactions can be expressed as

$$
q_{r x}=-\left(r_{\text {perh }} \cdot \Delta H_{R, p e r h}+r_{\text {decomp_PAA }} \cdot \Delta H_{R, \text { decomp_PAA }}\right) \cdot V_{a q}-\left(r_{E p} \cdot \Delta H_{R, E p}+r_{R O} \cdot \Delta H_{R, R O}\right) \cdot V_{o r g}
$$

The reaction enthalpy for acetic perhydrolysis is $-5.66 \mathrm{~kJ} \mathrm{~mol}^{-1}[50]$, epoxidation of unsaturated groups by percarboxylic acid is $-230 \mathrm{~kJ}^{-\mathrm{mol}^{-1}}[37]$ and for the ring-opening reactions is $-77 \mathrm{~kJ} . \mathrm{mol}^{-1}$ [37]. Furthermore, reaction enthalpy for the decomposition of PAA can be estimated from the heat of formation (see Table 2) as

$$
\Delta H_{R, \text { decomp }_{-} P A A}=2 * \Delta H_{f, A A}+\Delta H_{f, \mathrm{MeOH}}+\Delta H_{f, \mathrm{CO}_{2}}+\Delta H_{f, O_{2}}-3 * \Delta H_{f, P A A}
$$

Thus, the reaction enthalpy of PAA decomposition can be estimated to be $-450.3 \mathrm{~kJ} . \mathrm{mol}^{-1}$. 
Table 2: Heat of formation.

\begin{tabular}{|l|c|c|}
\cline { 2 - 3 } \multicolumn{1}{l|}{} & $\Delta H_{f}(\mathrm{~kJ} / \mathrm{mol})$ & References \\
\hline Acetic acid & -484.5 & {$[56]$} \\
\hline Peracetic acid & -390.1 & {$[57]$} \\
\hline Carbon dioxide in aqueous & & {$[58]$} \\
\hline solution & -413.25 & {$[59]$} \\
\hline Methanol & -283.4 & \\
\hline Oxygen & 0.0 & \\
\hline
\end{tabular}




\subsection{Kinetic modeling}

ModEst software [60] is used during the modeling stage. The set of ordinary differential equations (Eqs. (9) to (15)) were solved using the ODESSA algorithm. Reaction temperature was an observable. The objective function $\theta$ was defined as:

$\theta=\sum\left(T_{i}-\widehat{T}_{\imath}\right)^{2}$

where, $T_{i}$ is the experimental temperature and $\widehat{T}_{\imath}$ is the temperature obtained from the model. The goal of this stage was to estimate the kinetic constants for the decomposition of PAA, the ring-opening reaction and epoxidation reaction. To decrease the correlation between the rate constant at one temperature and the activation energy, a modified Arrhenius equation was used:

$k_{j}\left(T_{R}\right)=k_{j}\left(T_{R e f}\right) * \exp \left(\frac{-E_{a_{j}}}{R}\left(\frac{1}{T_{R}}-\frac{1}{T_{R e f}}\right)\right)$

where, $\mathrm{T}_{\text {ref }}$ is a reference temperature which was fixed to $90^{\circ} \mathrm{C}$ in this study.

The objective function was firstly minimized by the Simplex algorithm then by the LevenbergMarquardt algorithm.

To evaluate the fitting of the model to the experimental data, a coefficient of determination was calculated as

$\mathrm{R}^{2}=1-\frac{\sum\left(\mathrm{T}_{i}-\widehat{T}_{i}\right)^{2}}{\sum\left(\mathrm{T}_{i}-\bar{T}\right)^{2}}$

where, $\bar{T}$ is the mean value of the experimental temperatures.

The value of $\mathrm{R}^{2}$ was found to be $96 \%$ revealing that the model fits correctly the experimental data, see also Figs 3. A-C, where one can notice a good correlation between observations and modeling. 
Table 3 shows the values of the kinetic constants. One can notice the standard errors are significantly low.

Table 3: Kinetic constants estimated at $90^{\circ} \mathrm{C}$ and statistical data.

\begin{tabular}{|c|c|c|c|}
\hline & \multirow[b]{2}{*}{ Estimated parameters } & \multirow[b]{2}{*}{ Standard error $(\%)$} \\
\hline & & & \\
\hline$k_{\text {Decomp_PAA }}\left(90^{\circ} \mathrm{C}\right)$ & {$\left[\mathrm{L} \cdot \mathrm{mol}^{-1} \cdot \mathrm{s}^{-1}\right]$} & $1.62 \mathrm{E}-07$ & 6.4 \\
\hline$E a_{\text {Decomp_PAA }}$ & {$\left[\mathrm{kJ} \cdot \mathrm{mol}^{-1}\right]$} & 180.00 & 0.0 \\
\hline$k_{R O}\left(90^{\circ} \mathrm{C}\right)$ & {$\left[\mathrm{L} \cdot \mathrm{mol}^{-1} \cdot \mathrm{s}^{-1}\right]$} & $1.30 \mathrm{E}-05$ & 28.0 \\
\hline$E a_{R O}$ & {$\left[\mathrm{~kJ} \cdot \mathrm{mol}^{-1}\right]$} & 147.0 & 4.7 \\
\hline$k_{E p}\left(90^{\circ} \mathrm{C}\right)$ & {$\left[\mathrm{L} . \mathrm{mol}^{-1} \cdot \mathrm{s}^{-1}\right]$} & $4.13 \mathrm{E}-05$ & 0.6 \\
\hline$E a_{E p}$ & {$\left[\mathrm{~kJ} . \mathrm{mol}^{-1}\right]$} & 79.2 & 0.4 \\
\hline
\end{tabular}

From the work of Leveneur et al. [50], the kinetic constant of acetic acid perhydrolysis $\left(k_{\text {perh }}\right)$ at $90^{\circ} \mathrm{C}$ is equal to $0.058 \mathrm{~L} \cdot \mathrm{mol}^{-1} \cdot \mathrm{s}^{-1}$ and the activation energy $\left(E a_{\text {perh }}\right)$ is equal to $75.58 \mathrm{~kJ} \cdot \mathrm{mol}^{-1}$. From Table 3, when the reaction temperature is lower than $109^{\circ} \mathrm{C}$, then the kinetics of epoxidation is faster than the ring-opening or decomposition of PAA. For higher reaction temperature, the kinetics of ringopening by peracetic acid is faster than epoxidation.

Figs 3. A-C show some fittings of the model to the experimental data. Fig 3A shows that the model can fit experiment performed in the absence of sulfuric acid. Experiments illustrated by Figs 3B and 3C were performed at different concentration of sulfuric acid. Nevertheless, one can notice that the model slightly overestimates the experimental temperature in the presence of sulfuric acid. This deviation might be due to the fact that the effect of protons on the kinetics is more complex. 


\section{RUN 1}

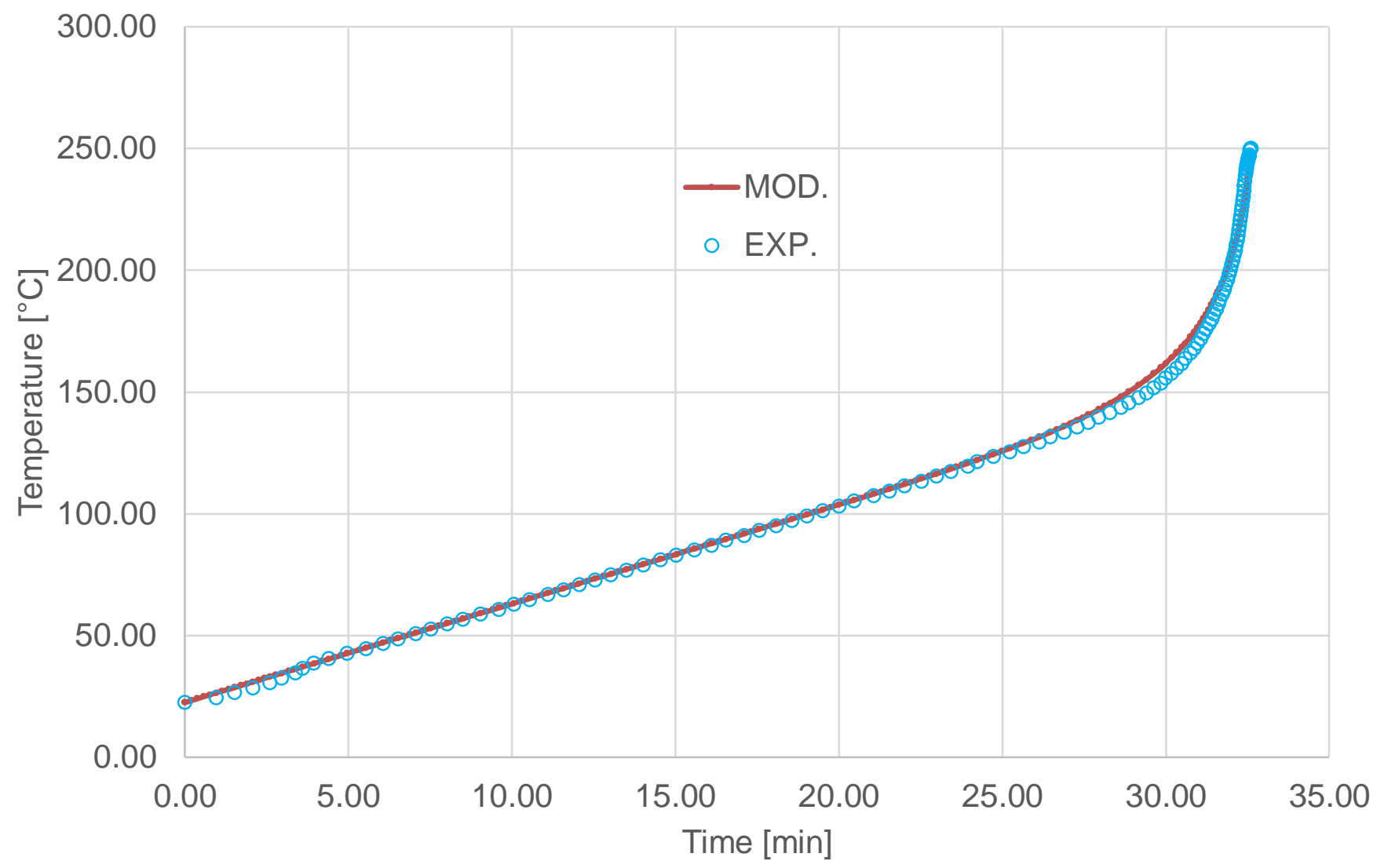

Figure 3.A: Fit of the model to the experimental data for Run 1. 


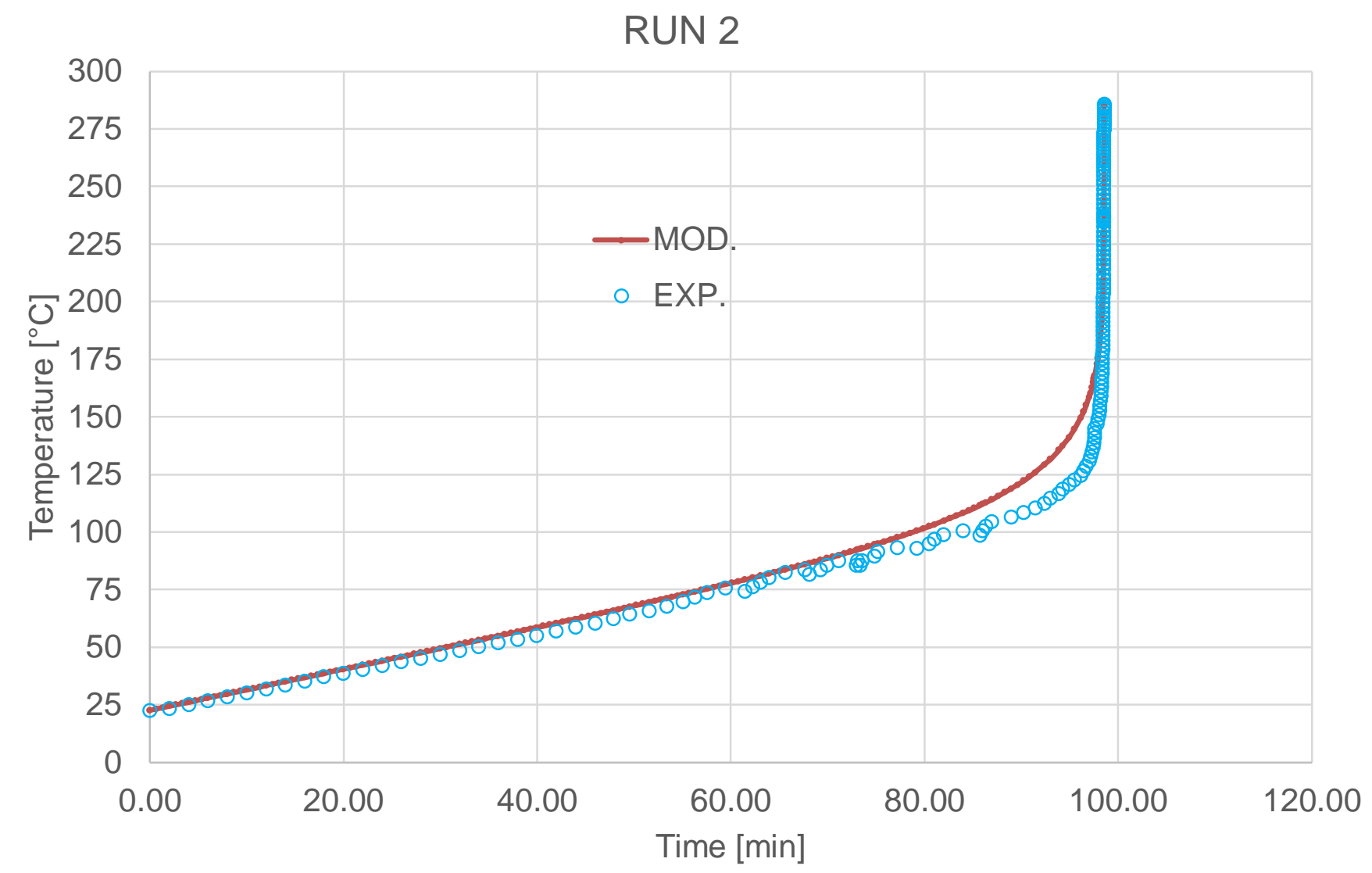

Figure 3.B: Fit of the model to the experimental data for Run 2. 


\section{RUN 4}

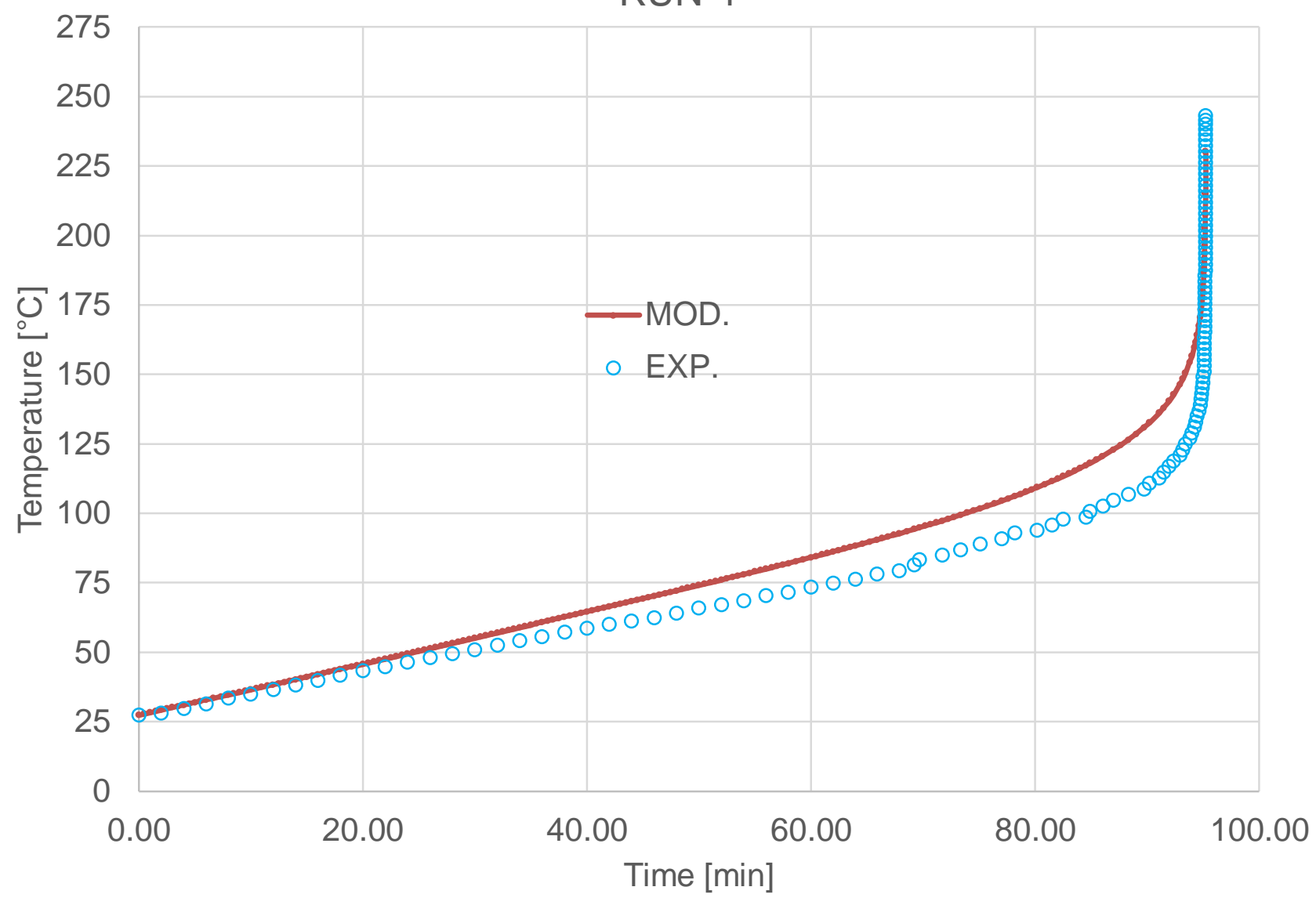

Figure 3.C: Fit of the model to the experimental data for Run 4. 


\subsection{Safety parameters.}

Thermal risk is defined by the product of the probability represented by $\mathrm{TMR}_{\mathrm{ad}}$ and severity represented by $\Delta \mathrm{T}_{\text {ad }}$ [61]. Based on the kinetic model, the influence of sulfuric acid, hydrogen peroxide, acetic acid concentrations and initial temperature on the safety parameters: $\mathrm{TMR}_{\mathrm{ad}}$ and $\Delta \mathrm{T}_{\text {ad. }}$. The parameter $\mathrm{TMR}_{\mathrm{ad}}$ represents the time it takes for a reaction mass to reach the maximum rate of heat release for a given starting temperature under adiabatic condition and the parameter $\Delta \mathrm{T}_{\mathrm{ad}}$ is the difference between the initial and the final temperatures.

These parameters were studied for the epoxidation of cottonseed oil under adiabatic condition in a batch reactor. Figs 4 to 7 illustrate the influence of these parameters. Fig. 4 shows that the increase of sulfuric acid concentration does not have a significant effect on $\Delta \mathrm{T}_{\text {ad. }}$. However, the increase of sulfuric acid concentration accelerates the kinetics of reaction, thus decreases the value of $\mathrm{TMR}_{\mathrm{ad}}$. 


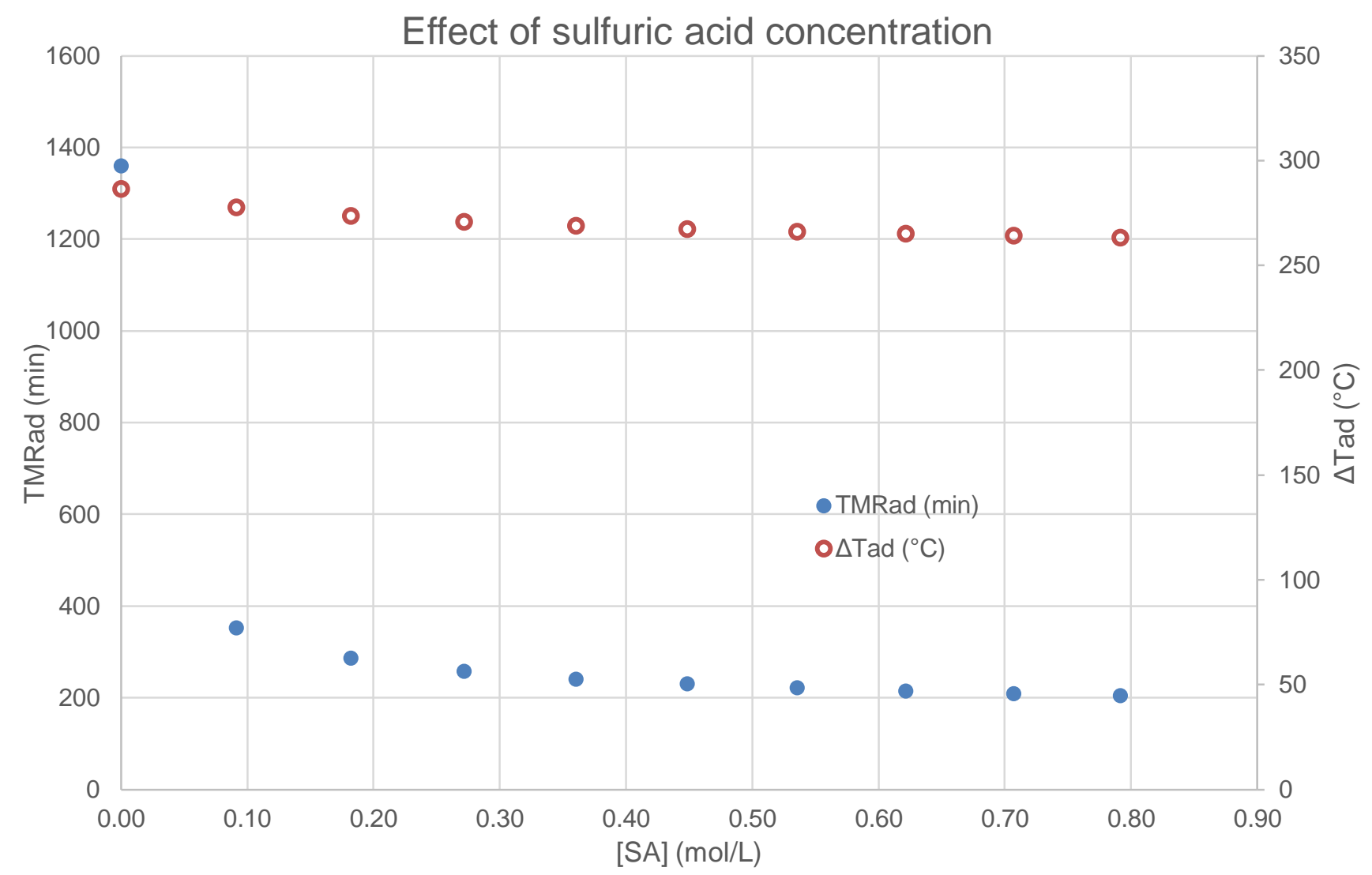

Figure 4: Effect of sulfuric acid concentration on $\mathrm{TMR}_{\mathrm{ad}}$ and $\Delta \mathrm{T}_{\mathrm{ad}}$ with the following operating conditions: $\left[\mathrm{H}_{2} \mathrm{O}_{2}\right]_{\mathrm{aq}, 0}=5.81-5.56 \mathrm{~mol} . \mathrm{L}^{-1},[\mathrm{AA}]_{\mathrm{aq}, 0}=6.11-5.85 \mathrm{~mol} . \mathrm{L}^{-1},[\mathrm{~W}]_{\mathrm{aq}, 0}=28.74-27.59 \mathrm{~mol} . \mathrm{L}^{-}$ ${ }^{1}$ and initial temperature of $70^{\circ} \mathrm{C}$.

Fig. 5 shows that the increase of the initial reaction temperature does not have a significant effect on the value of $\Delta \mathrm{T}_{\mathrm{ad}}$. By increasing the initial temperature, the kinetics is faster, thus the $\mathrm{TMR}_{\mathrm{ad}}$ is shorter. 


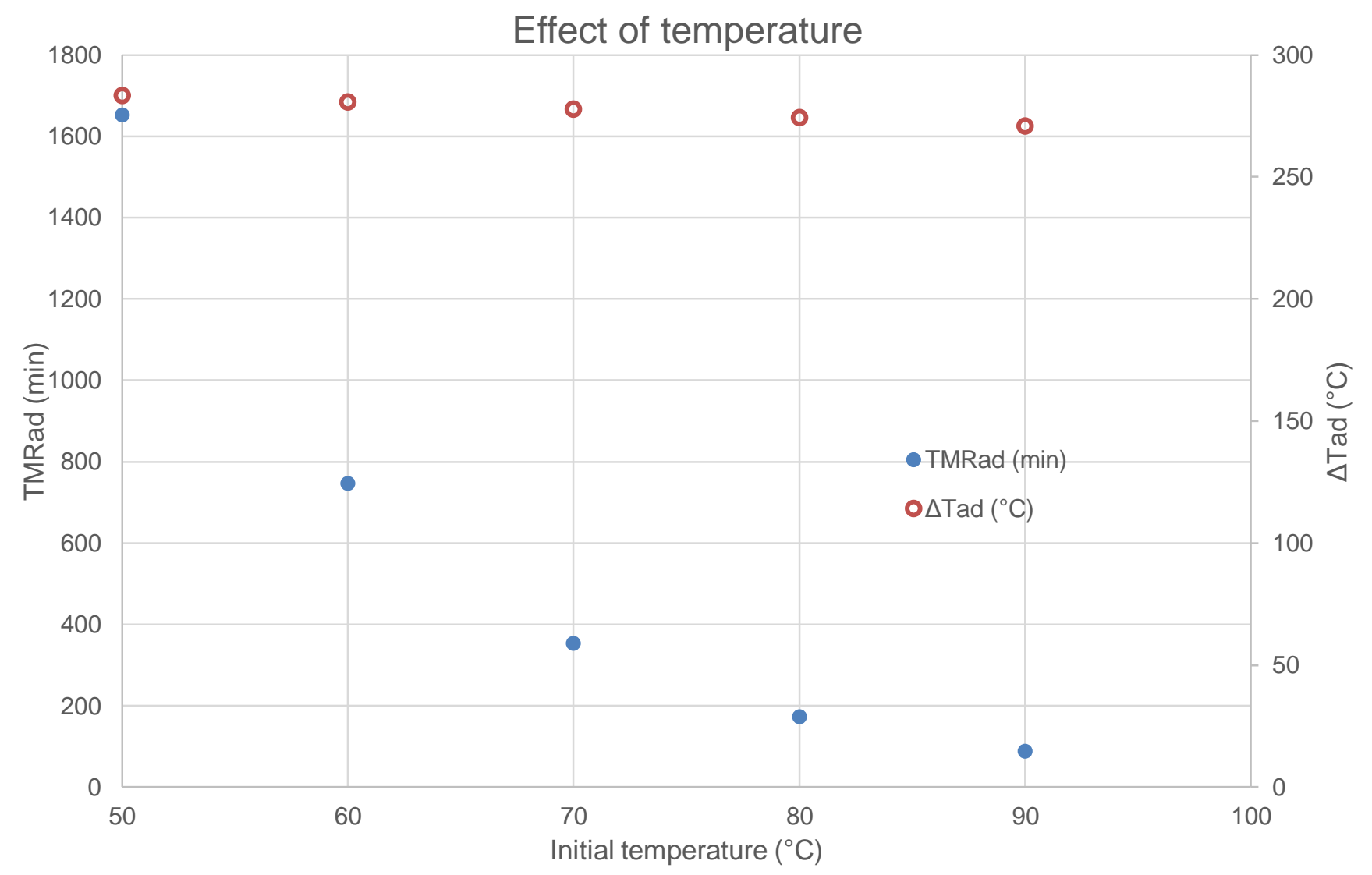

Figure 5: Effect of initial temperature on $\mathrm{TMR}_{\mathrm{ad}}$ and $\Delta \mathrm{T}_{\mathrm{ad}}$ with the following operating conditions:

$$
\begin{gathered}
{\left[\mathrm{H}_{2} \mathrm{O}_{2}\right]_{\mathrm{aq}, 0}=5.79 \mathrm{~mol} \cdot \mathrm{L}^{-1},[\mathrm{AA}]_{\mathrm{aq}, 0}=6.08 \mathrm{~mol} \cdot \mathrm{L}^{-1},[\mathrm{~W}]_{\mathrm{aq}, 0}=28.60 \mathrm{~mol} \cdot \mathrm{L}^{-1} \text { and initial }\left[\mathrm{H}_{2} \mathrm{SO}_{4}\right]_{\mathrm{aq}, 0}=} \\
0.09 \mathrm{~mol} \cdot \mathrm{L}^{-1} .
\end{gathered}
$$

The increase of hydrogen peroxide concentration increases the adiabatic temperature rise and the values of $\mathrm{TMR}_{\mathrm{ad}}$, as depicted in Fig. 6. By increasing the concentration of hydrogen peroxide, the kinetics of peracetic acid production and epoxidation are faster leading to shorten $\mathrm{TMR}_{\mathrm{ad}}$. In addition, the increase of hydrogen peroxide concentration leads to increase the production of peracetic acid and its decomposition involving an increase of $\Delta \mathrm{T}_{\mathrm{ad}}$. 


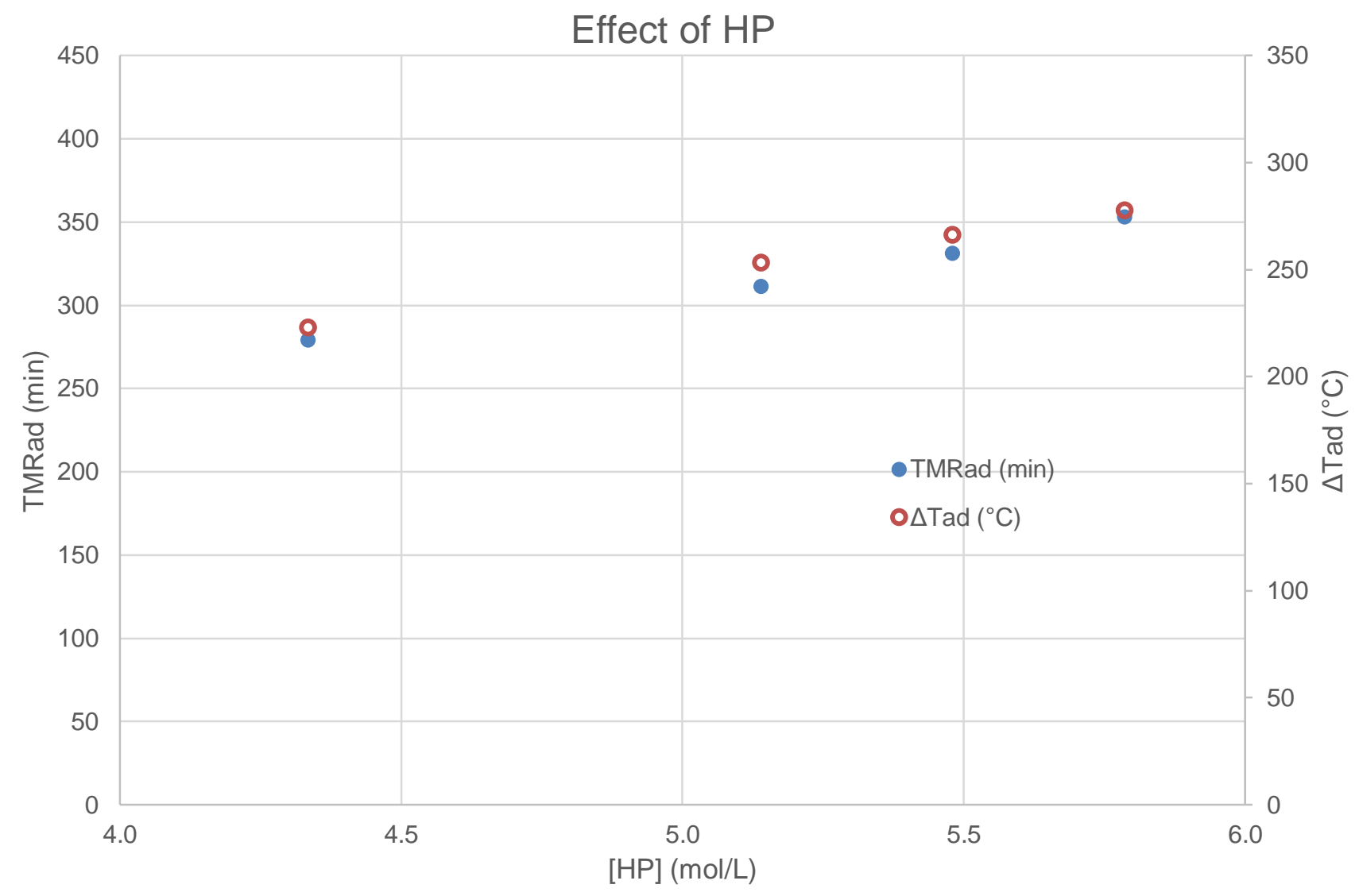

Figure 6: Effect of hydrogen peroxide concentration on $\mathrm{TMR}_{\mathrm{ad}}$ and $\Delta \mathrm{T}_{\mathrm{ad}}$ with the following operating conditions: $[\mathrm{AA}]_{\mathrm{aq}, 0}=5.53-7.60 \mathrm{~mol} . \mathrm{L}^{-1},[\mathrm{~W}]_{\mathrm{aq}, 0}=29.71-25.57 \mathrm{~mol} . \mathrm{L}^{-1},\left[\mathrm{H}_{2} \mathrm{SO}_{4}\right]_{\mathrm{aq}, 0}=0.08-$ $0.11 \mathrm{~mol} . \mathrm{L}^{-1}$ and initial temperature of $70^{\circ} \mathrm{C}$.

Inversely to the behavior of hydrogen peroxide, the increase of acetic acid concentration decreases the adiabatic temperature rise and the values of $\mathrm{TMR}_{\mathrm{ad}}$ as expressed in Fig. 7. Indeed, by increasing the concentration of acetic acid compared to hydrogen peroxide, thus hydrogen perxode is the limiting reactant which leads to decrease the production of PAA. 


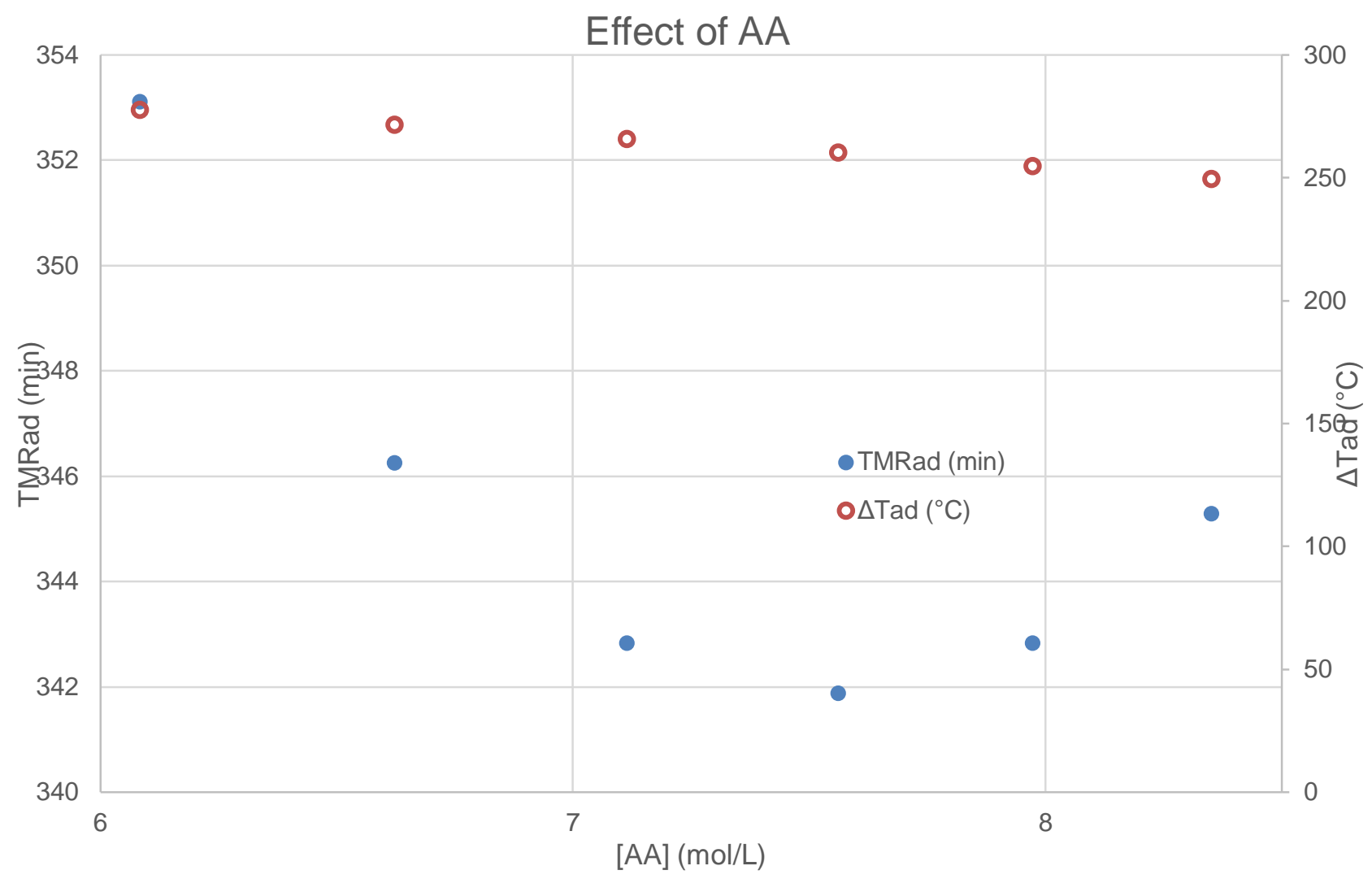

Figure 7: Effect of acetic acid concentration on $\mathrm{TMR}_{\mathrm{ad}}$ and $\Delta \mathrm{T}_{\mathrm{ad}}$ with the following operating conditions: $\left[\mathrm{H}_{2} \mathrm{O}_{2}\right]_{\mathrm{aq}, 0}=5.79-4.63 \mathrm{~mol} . \mathrm{L}^{-1},[\mathrm{~W}]_{\mathrm{aq}, 0}=28.60-22.91 \mathrm{~mol} . \mathrm{L}^{-1},\left[\mathrm{H}_{2} \mathrm{SO}_{4}\right]_{\mathrm{aq}, 0}=0.09-0.07$ mol. $\mathrm{L}^{-1}$ and initial temperature of $70^{\circ} \mathrm{C}$.

The observation made from Figs 4 to 7, indicates that concentrations of acetic acid and hydrogen peroxide have an important impact on safety parameters. Concentration of double bond could also have an impact on these parameters, but at time zero fresh vegetable oils were used.

Furthermore, one can notice that the adiabatic temperature rise is critical because it is higher than $200^{\circ} \mathrm{C}$ and $\mathrm{TMR}_{\mathrm{ad}}$ is frequent or critical because the values are lower than 8 hours [61]. The time to react is then not enough. 


\section{CONCLUSIONS}

Epoxidation of vegetable oils is an important process for polymer industries, because epoxidized vegetable oils can be seen as platform molecules. In industry, Prileschajew oxidation is used, which consists of the in situ production of a percarboxylic acid in the aqueous phase. This percarboxylic acid diffuses to the organic phase to epoxidize the unsaturated groups. Several studies have built kinetic model under isothermal or isoperibolic conditions, and other studies have stressed their effort on the thermal risk of this reaction system. Nevertheless, no research work so far, to our best knowledge, have proposed a kinetic model under adiabatic condition.

In this study, we have built a kinetic model for the epoxidation of cottonseed oil by peracetic acid under near-adiabatic condition. The following reactions were considered: perhydrolysis of acetic acid, decomposition of peracetic acid, epoxidation of unsaturated groups and ring-opening reaction by peracetic acid. Mass transfer was assumed to be faster than chemical reactions allowing to simplify the model. The model fits the experimental reaction temperature correctly.

The chosen safety parameters, time-to-maximum rate under adiabatic condition and adiabatic temperature rise, were estimated by this model under different operating conditions. The benefit of such model is to avoid the use of a zero-order kinetic model which cannot describe a system at different operating conditions. It was found that these two parameters were sensitive to the concentrations of acetic acid and hydrogen peroxide.

It is noted that the kinetic model developed in this study was built based on the evolution of the experimental temperature under adiabatic condition and not based on the evolution of the species concentrations. A further work could be the use of an online analytical method to follow the concentration of double bonds, epoxide, PAA or ring-opening group under adiabatic conditions to improve the model. 


\section{ACKNOWLEDGEMENTS}

The authors thank the Maitrise des Risques et Environementaux and Chimie Fine et Ingénierie departments. 


\section{NOMENCATURE}

\begin{tabular}{|c|c|}
\hline$\hat{C}_{P_{R}}$ & Specific heat-capacity $\left[\mathrm{J} \cdot \mathrm{kg}^{-1} \cdot \mathrm{K}^{-1}\right]$ \\
\hline $\mathrm{Ea}$ & Activation energy $\left[\mathrm{J} \cdot \mathrm{mol}^{-1}\right]$ \\
\hline$\Delta \mathrm{H}$ & Reaction enthalpy $\left[\mathrm{J} \cdot \mathrm{mol}^{-1}\right]$ \\
\hline $\mathrm{k}$ & Rate constant \\
\hline $\mathrm{K}$ & Equilibrium constant \\
\hline $\mathrm{K}_{i}=$ & Distribution coefficient $\left(\frac{C_{i, a q}}{C_{i, o r g}}\right)_{\text {equilibrium }}$ \\
\hline $\mathrm{m}_{\text {ins }}$ & Insert mass $[\mathrm{kg}]$ \\
\hline $\mathrm{m}_{\mathrm{R}}$ & Mass of reaction mixture $[\mathrm{kg}]$ \\
\hline qel & Electrical heating-rate $\left[{ }^{\circ} \mathrm{C} \cdot \mathrm{min}^{-1}\right]$ \\
\hline $\mathrm{q}_{\mathrm{rx}}$ & Heat-flow rate due to chemical reactions $\left[{\left.\mathrm{J} . \mathrm{s}^{-1}\right]}^{-1}\right]$ \\
\hline $\mathrm{R}$ & Gas constant $\left[\mathrm{J} \cdot \mathrm{K}^{-1} \cdot \mathrm{mol}^{-1}\right]$ \\
\hline $\mathrm{R}^{2}$ & Coefficient of determination [\%] \\
\hline$\Delta \mathrm{T}_{\mathrm{ad}}$ & Adiabatic temperature rise $\left[{ }^{\circ} \mathrm{C}\right]$ \\
\hline $\mathrm{T}_{1}$ & Temperature of the reaction mixture $\left[{ }^{\circ} \mathrm{C}\right]$ \\
\hline $\mathrm{T}_{\text {Ref }}$ & Reference temperature $\left[{ }^{\circ} \mathrm{C}\right]$ \\
\hline$T_{i}$ & Experimental temperature \\
\hline$T_{P}$ & Process temperature \\
\hline $\bar{T}$ & Mean value of the experimental temperatures \\
\hline$\widehat{T}_{i}$ & Simulated temperature \\
\hline $\mathrm{V}$ & Volume [L] \\
\hline
\end{tabular}


Greek letters

$\begin{array}{ll}\alpha & \frac{V_{a q}}{V_{T}} \\ \beta & \text { Background heating rate }\left[{ }^{\circ} \mathrm{C} \cdot \mathrm{min}^{-1}\right] \\ \delta & \text { Parameter taking into account the non-ideality of the solution } \\ \varphi & \text { Thermal inertia } \\ \theta & \text { Objective function }\end{array}$

Abbreviations

AA

ARSST

DB

HP

PAA

RO

$\mathrm{TMR}_{\mathrm{ad}}\left(\mathrm{T}_{\mathrm{P}}\right)$

W
Acetic acid

Advanced Reactive System Screening Tool

Double bond

Hydrogen peroxide

Peracetic acid

Ring-opening

Time-to-maximum rate under adiabatic conditions at $\mathrm{T}_{\mathrm{P}}$ [min]

Water 


$\begin{array}{ll}\text { Subscript } & \\ \text { aq } & \text { Aqueous } \\ \text { decompo_PAA } & \text { Decomposition of PAA } \\ \text { Ep } & \text { Epoxidation } \\ \text { ins } & \text { Insert } \\ \mathrm{j} & \text { Reaction } \\ \text { org } & \text { Organic } \\ \text { perh } & \text { Perhydrolysis } \\ \mathrm{T} & \text { Total } \\ 0 & \text { Initial }\end{array}$




\section{REFERENCES}

[1] J.G. Speight, Environmental Organic Chemistry for Engineers, Butterworth-Heinemann, 2016.

[2] F. Rosillo-Calle, L. Pelkmans, A. Walter. A Global Overview of Vegetable Oils, with Reference to Biodiesel. Report of IEA Bioenergy, 2009.

[3] T. Issariyakul, A.K. Dalai, Biodiesel from vegetable oils, Renewable Sustainable Energy Rev. 31 (2014) 446-471. doi:10.1016/j.rser.2013.11.001.

[4] B. Nohra, L. Candy, J.-F. Blanco, C. Guerin, Y. Raoul, Z. Mouloungui, From petrochemical polyurethanes to biobased polyhydroxyurethanes, Macromolecules. 46 (2013) 3771-3792. doi:10.1021/ma400197c.

[5] G. Lligadas, J.C. Ronda, M. Galià, V. Cádiz, Renewable polymeric materials from vegetable oils: a perspective, Materials Today. 16 (2013) 337-343. doi:10.1016/j.mattod.2013.08.016.

[6] J.C. Ronda, G. Lligadas, M. Galià, V. Cádiz, Vegetable oils as platform chemicals for polymer synthesis, Eur. J. Lipid Sci. Technol. 113 (2011) 46-58. doi:10.1002/ejlt.201000103.

[7] J.L. Zheng, F. Burel, T. Salmi, B. Taouk, S. Leveneur, Carbonation of vegetable oils: influence of mass transfer on reaction kinetics, Ind. Eng. Chem. Res. 54 (2015) 10935-10944. doi:10.1021/acs.iecr.5b02006.

[8] G. Rokicki, P.G. Parzuchowski, M. Mazurek, Non-isocyanate polyurethanes: synthesis, properties, and applications, Polym. Adv. Technol. 26 (2015) 707-761. doi:10.1002/pat.3522.

[9] O. Kreye, H. Mutlu, M.A.R. Meier, Sustainable routes to polyurethane precursors, Green Chemistry 15 (2013) 1431-1455. doi:10.1039/C3GC40440D.

[10] M. Bähr, R. Mülhaupt, Linseed and soybean oil-based polyurethanes prepared via the nonisocyanate route and catalytic carbon dioxide conversion, Green Chem. 14 (2012) 483-489. doi:10.1039/C2GC16230J. 
[11] M. Jalilian, H. Yeganeh, M.N. Haghighi, Preparation and characterization of polyurethane electrical insulating coatings derived from novel soybean oil-based polyol, Polym. Adv. Technol. 21 (2010) 118-127. doi:10.1002/pat.1406.

[12] I. Javni, D.P. Hong, Z.S. Petrović, Soy-based polyurethanes by nonisocyanate route, J. Appl. Polym. Sci. 108 (2008) 3867-3875. doi:10.1002/app.27995.

[13] B. Tamami, S. Sohn, G.L. Wilkes, Incorporation of carbon dioxide into soybean oil and subsequent preparation and studies of nonisocyanate polyurethane networks, J. Appl. Polym. Sci. 92 (2004) 883-891. doi:10.1002/app.20049.

[14] L. Zhang, Y. Luo, Z. Hou, Z. He, W. Eli, Synthesis of carbonated cotton seed oil and its application as lubricating base oil, J. Am. Oil Chem. Soc. 91 (2014) 143-150. doi:10.1007/s11746013-2358-1.

[15] A. Campanella, E. Rustoy, A. Baldessari, M.A. Baltanás, Lubricants from chemically modified vegetable oils, Bioresource Technology. 101 (2010) 245-254. doi:10.1016/j.biortech.2009.08.035.

[16] P.S. Lathi, B. Mattiasson, Green approach for the preparation of biodegradable lubricant base stock from epoxidized vegetable oil, Appl. Catal., B. 69 (2007) 207-212. doi:10.1016/j.apcatb.2006.06.016.

[17] H.-S. Hwang, S.Z. Erhan, Synthetic lubricant basestocks from epoxidized soybean oil and Guerbet alcohols, Ind. Crops Prod. 23 (2006) 311-317. doi:10.1016/j.indcrop.2005.09.002.

[18] H.-S. Hwang, S.Z. Erhan, Modification of epoxidized soybean oil for lubricant formulations with improved oxidative stability and low pour point, J. Am. Oil Chem. Soc. 78 (2001) 1179-1184. doi:10.1007/s11745-001-0410-0.

[19] R.N. Darie-Niţă, C. Vasile, A. Irimia, R. Lipşa, M. Râpă, Evaluation of some eco-friendly plasticizers for PLA films processing, J. Appl. Polym. Sci. 133 (2016) n/a-n/a. 
doi:10.1002/app.43223.

[20] B. Bouchareb, M.T. Benaniba, Effects of epoxidized sunflower oil on the mechanical and dynamical analysis of the plasticized poly(vinyl chloride), J. Appl. Polym. Sci. 107 (2008) 34423450. doi:10.1002/app.27458.

[21] A. Köckritz, A. Martin, Oxidation of unsaturated fatty acid derivatives and vegetable oils, Eur. J. Lipid Sci. Technol. 110 (2008) 812-824. doi:10.1002/ejlt.200800042.

[22] B.B. Wentzel, P.L. Alsters, M.C. Feiters, R.J.M. Nolte, Mechanistic studies on the mukaiyama epoxidation, J. Org. Chem. 69 (2004) 3453-3464. doi:10.1021/jo030345a.

[23] T.-C. Chou, S.-V. Lee, Epoxidation of oleic acid in the presence of benzaldehyde using cobalt(ii) tetraphenylporphyrin as catalyst, Ind. Eng. Chem. Res. 36 (1997) 1485-1490. doi:10.1021/ie960454y.

[24] P. Aguirre, S. Zolezzi, J. Parada, E. Bunel, S.A. Moya, R. Sariego, Ruthenium carbonyl complexes in catalytic epoxidation of olefins co-catalyzed by isobutyl-aldehyde, Appl. Organometal. Chem. 20 (2006) 260-263. doi:10.1002/aoc.1044.

[25] M. Di Serio, R. Turco, P. Pernice, A. Aronne, F. Sannino, E. Santacesaria, Valuation of Nb2O5$\mathrm{SiO} 2$ catalysts in soybean oil epoxidation, Catalysis Today. 192 (2012) 112-116. doi:10.1016/j.cattod.2012.03.069.

[26] I.W.C.E. Arends, R.A. Sheldon, Recent developments in selective catalytic epoxidations with $\mathrm{H}_{2} \mathrm{O}_{2}$, Topics in Catalysis. 19 (2002) 133-141. doi:10.1023/A:1013897703249.

[27] M.E. Abraham, R.F. Benenati, Kinetics and mechanism of the epoxidation of unsaturated fatty acids, AIChE J. 18 (1972) 807-811. doi:10.1002/aic.690180424.

[28] A. Campanella, M.A. Baltanás, M.C. Capel-Sánchez, J.M. Campos-Martín, J.L.G. Fierro, Soybean oil epoxidation with hydrogen peroxide using an amorphous $\mathrm{Ti} / \mathrm{SiO}_{2}$ catalyst, Green Chem. 
6 (2004) 330-334. doi:10.1039/B404975F.

[29] C. Aouf, E. Durand, J. Lecomte, M.-C. Figueroa-Espinoza, E. Dubreucq, H. Fulcrand, P. Villeneuve, The use of lipases as biocatalysts for the epoxidation of fatty acids and phenolic compounds, Green Chem. 16 (2014) 1740-1754. doi:10.1039/C3GC42143K.

[30] A.E.V. Hagström, U. Törnvall, M. Nordblad, R. Hatti-Kaul, J.M. Woodley, Chemo-enzymatic epoxidation-process options for improving biocatalytic productivity, Biotechnol Progress. 27 (2011) 67-76. doi:10.1002/btpr.504.

[31] H. Lu, S. Sun, Y. Bi, G. Yang, R. Ma, H. Yang, Enzymatic epoxidation of soybean oil methyl esters in the presence of free fatty acids, Eur. J. Lipid Sci. Technol. 112 (2010) 1101-1105. doi:10.1002/ejlt.201000041.

[32] U. Törnvall, C. Orellana-Coca, R. Hatti-Kaul, D. Adlercreutz, Stability of immobilized Candida antarctica lipase B during chemo-enzymatic epoxidation of fatty acids, Enzyme and Microbial Technology. 40 (2007) 447-451. doi:10.1016/j.enzmictec.2006.07.019.

[33] C. Orellana-Coca, J.M. Billakanti, B. Mattiasson, R. Hatti-Kaul, Lipase mediated simultaneous esterification and epoxidation of oleic acid for the production of alkylepoxystearates, J. Mol. Catal. B: Enzym. 44 (2007) 133-137. doi:10.1016/j.molcatb.2006.09.002.

[34] C. Orellana-Coca, D. Adlercreutz, M.M. Andersson, B. Mattiasson, R. Hatti-Kaul, Analysis of fatty acid epoxidation by high performance liquid chromatography coupled with evaporative light scattering detection and mass spectrometry, Chem. Phys. Lipids. 135 (2005) 189-199. doi:10.1016/j.chemphyslip.2005.02.014.

[35] I. Hilker, D. Bothe, J. Prüss, H.-J. Warnecke, Chemo-enzymatic epoxidation of unsaturated plant oils, Chem. Eng. Sci. 56 (2001) 427-432. doi:10.1016/S0009-2509(00)00245-1.

[36] M. Rüsch gen. Klaas, S. Warwel, Complete and partial epoxidation of plant oils by lipase- 
catalyzed perhydrolysis, Ind. Crops Prod. 9 (1999) 125-132. doi:10.1016/S0926-6690(98)00023-5. [37] J.L. Zheng, J. Wärnå, T. Salmi, F. Burel, B. Taouk, S. Leveneur, Kinetic modeling strategy for an exothermic multiphase reactor system: Application to vegetable oils epoxidation using Prileschajew method, AIChE J. 62 (2016) 726-741. doi:10.1002/aic.15037.

[38] S. Leveneur, J. Zheng, B. Taouk, F. Burel, J. Wärnå, T. Salmi, Interaction of thermal and kinetic parameters for a liquid-liquid reaction system: Application to vegetable oils epoxidation by peroxycarboxylic acid, J. Taiwan Inst. Chem. E. 45 (2014) 1449-1458. doi:10.1016/j.jtice.2014.01.015.

[39] B. Cortese, M.H.J.M. de Croon, V. Hessel, High-Temperature Epoxidation of Soybean Oil in Flow-Speeding up Elemental Reactions Wanted and Unwanted, Ind. Eng. Chem. Res. 51 (2012) 1680-1689. doi:10.1021/ie200868w.

[40] E. Santacesaria, R. Tesser, M. Di Serio, R. Turco, V. Russo, D. Verde, A biphasic model describing soybean oil epoxidation with $\mathrm{H}_{2} \mathrm{O}_{2}$ in a fed-batch reactor, Chemical Engineering Journal. 173 (2011) 198-209. doi:10.1016/j.cej.2011.05.018.

[41] A. Campanella, C. Fontanini, M.A. Baltanás, High yield epoxidation of fatty acid methyl esters with performic acid generated in situ, Chemical Engineering Journal. 144 (2008) 466-475. doi:10.1016/j.cej.2008.07.016.

[42] S. Leveneur, Thermal Safety Assessment through the Concept of Structure-Reactivity: Application to Vegetable Oil Valorization, Org. Process Res. Dev. 21 (2017) 543-550. doi:10.1021/acs.oprd.6b00405.

[43] V. Casson Moreno, V. Russo, R. Tesser, M. Di Serio, E. Salzano, Thermal risk in semi-batch reactors: The epoxidation of soybean oil, Process Safety and Environmental Protection. 109 (2017) 529-537. doi:10.1016/j.psep.2017.05.001. 
[44] H. Rakotondramaro, J. Wärnå, L. Estel, T. Salmi, S. Leveneur, Cooling and stirring failure for semi-batch reactor: Application to exothermic reactions in multiphase reactor, Journal of Loss Prevention in the Process Industries. 43 (2016) 147-157. doi:10.1016/j.jlp.2016.05.011.

[45] J.V. de Quadros Jr., R. Giudici, Epoxidation of soybean oil at maximum heat removal and single addition of all reactants, Chemical Engineering and Processing: Process Intensification. 100 (2016) 87-93. doi:10.1016/j.cep.2015.11.007.

[46] K. Ait Aissa, J.L. Zheng, L. Estel, S. Leveneur, Thermal Stability of Epoxidized and Carbonated Vegetable Oils, Org. Process Res. Dev. 20 (2016) 948-953. doi:10.1021/acs.oprd.6b00040.

[47] S. Leveneur, L. Estel, C. Crua, Thermal Risk Assessment of Vegetable Oil Epoxidation, J Therm Anal Calorim. 122 (2015) 795-804. doi:10.1007/s10973-015-4793-8.

[48] E. Salzano, A.G. Agreda, V. Russo, M. Di Serio, E. Santacesaria, Safety Criteria for the Epoxydation of Soybean Oil in Fed-Batch Reactor, Chem. Eng. Trans. 26 (2009) 39-44.

[49] L. Vernières-Hassimi, A. Dakkoune, L. Abdelouahed, L. Estel, S. Leveneur, Zero-Order Versus Intrinsic Kinetics for the Determination of the Time to Maximum Rate under Adiabatic Conditions (TMRad): Application to the Decomposition of Hydrogen Peroxide, Ind. Eng. Chem. Res. 56 (2017) 13040-13049. doi:10.1021/acs.iecr.7b01291.

[50] S. Leveneur, J. Wärnå, T. Salmi, D.Y. Murzin, L. Estel, Interaction of Intrinsic Kinetics and Internal Mass Transfer in Porous Ion-Exchange Catalysts: Green synthesis of Peroxycarboxylic Acids, Chemical Engineering Science. 64 (2009) 4101-4114. doi:10.1016/j.ces.2009.05.055.

[51] K. Sue, F. Ouchi, K. Minami, K. Arai, Determination of Carboxylic Acid Dissociation Constants to $350{ }^{\circ} \mathrm{C}$ at $23 \mathrm{MPa}$ by Potentiometric pH Measurements, J. Chem. Eng. Data. 49 (2004) 1359-1363. doi:10.1021/je049923q.

[52] D.A. Knopf, B.P. Luo, U.K. Krieger, T. Koop, Thermodynamic Dissociation Constant of the 
Bisulfate Ion from Raman and Ion Interaction Modeling Studies of Aqueous Sulfuric Acid at Low Temperatures, J. Phys. Chem. A. 107 (2003) 4322-4332. doi:10.1021/jp027775+.

[53] N. Musakka, T. Salmi, J. Wärnå, J. Ahlkvist, M. Piironen, Modelling of organic liquid-phase decomposition reactions through gas-phase product analysis: Model systems and peracetic acid, Chemical Engineering Science. 61 (2006) 6918-6928. doi:10.1016/j.ces.2006.07.033.

[54] S. Leveneur, T. Salmi, N. Musakka, J. Wärnå, Kinetic study of decomposition of peroxypropionic acid in liquid phase through direct analysis of decomposition products in gas phase, Chemical Engineering Science. 62 (2007) 5007-5012. doi:10.1016/j.ces.2006.12.040.

[55] E. Marco, S. Cuartielles, J.A. Peña, J. Santamaria, Simulation of the decomposition of di-cumyl peroxide in an ARSST unit, Thermochimica Acta. 362 (2000) 49-58. doi:10.1016/S00406031(00)00587-6.

[56] Lide, D. R., CRC Handbook of Chemistry and Physics, 75th edition, CRC Press, Boca Raton, Florida, 1995.

[57] S. Havel, J. Greschner, Explosion properties of peroxyacetic acid. I. Thermodynamic calculation of the explosion characteristics of peroxyacetic acid, Chem. Prum. 16 (1966) 73-78.

[58] R.L. Berg, C.E. Vanderzee, Thermodynamics of carbon dioxide and carbonic acid: (a) the standard enthalpies of solution of $\mathrm{Na} 2 \mathrm{CO} 3(\mathrm{~s}), \mathrm{NaHCO} 3(\mathrm{~s})$, and $\mathrm{CO} 2(\mathrm{~g})$ in water at $298.15 \mathrm{~K}$; (b) the standard enthalpies of formation, standard Gibbs energies of formation, and standard entropies of $\mathrm{CO} 2(\mathrm{aq}), \quad \mathrm{HCO} 3-(\mathrm{aq}), \quad \mathrm{CO} 32-(\mathrm{aq}), \quad \mathrm{NaHCO} 3(\mathrm{~s}), \quad \mathrm{Na} 2 \mathrm{CO} 3(\mathrm{~s}), \quad \mathrm{Na} 2 \mathrm{CO} 3 \cdot \mathrm{H} 2 \mathrm{O}(\mathrm{s}), \quad$ and Na2CO3·10H2O(s), J. Chem. Thermodyn. 10 (12) (1978) 1113-1136. https://doi.org/10.1016/0021$\underline{9614(78) 90029-0}$

[59] E.E. Baroody, G.A. Carpenter, Heats of formation of propellant compounds. Rpt. Naval Ordnance Systems Command Task No. 331-003/067-1/UR2402-001 for Naval Ordance Station, 
Indian Head, MD, 1-9, 1972.

[60] H. Haario, MODEST-User’s Guide, Profmath Oy, Helsinki, 1994.

[61] Stoessel, F., Thermal Safety of Chemical Processes. Wiley-VCH Verlag GmbH \& Co. KGaA, Weinheim, 2008. 